\title{
How do you Jew in Finland?
}

\author{
BoOK REVIEW
}

DOI: https://doi.org/10.30752/nj.112296

Mercédesz Czimbalmos: Intermarriage, Conversion and Jewish Identity in Contemporary Finland. A Study of Vernacular Religion in the Finnish Jewish Communities (Åbo Akademi University, 2021), <https://urn.fi/ URN:ISBN:978-952-12-4038-6>.

Mercédesz Czimbalmos's doctoral dissertation Intermarriage, Conversion and Jewish Identity in Contemporary Finland is a 'compilation thesis', that is a thesis consisting of previously published articles and an introductory chapter summarising the research. Four articles form the basis of the dissertation: 'Laws, doctrines and practice: a study of intermarriages and the ways they challenged the Jewish Community of Helsinki from I 930 to I970', published in Scandinavian Jewish Studies 30(I): 35-54 in 201 9; "Everyone does Jewish in their own way": vernacular practices of intermarried Finnish Jewish women', published in Approaching Religion I (2): 53-72 in 2020; 'Yidishe tates forming Jewish families: experiences of intermarried Finnish Jewish men', published in Scandinavian Jewish Studies 3I(2): 21-40 in 2020; and 'Rites of passage: conversionary in-marriages in the Finnish Jewish communities', forthcoming in Journal of Religion in Europe in $202 \mathrm{I}$.

The dissertation, defended at Åbo Akademi University in June $202 \mathrm{I}$, is a part of the project 'Boundaries of Jewish Identities

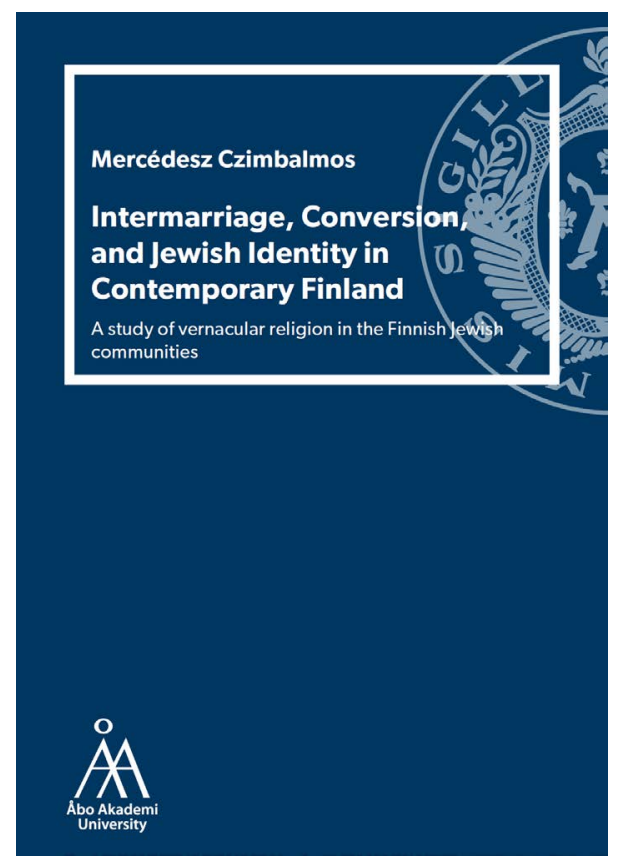

in Contemporary Finland', perhaps better known as 'Minhag Finland'. This review focuses on the introductory chapter, introducing the starting points and summarising the main results.

Intermarriage, Conversion and Jewish Identity in Contemporary Finland is a solid doctoral dissertation, cohesive, stringent, concise and well-argued. Mercédesz Czimbalmos clearly states what she aims to do, which concepts she will use, and how, and does what she sets out to do, and in a systematic fashion. The aim is clearly stated, the questions are reasonable, the perspective rewarding, the 
sources and methods used relevant, and the results convincing.

The aim of the study is 'to explore vernacular practices of the two congregations [Helsinki and Turku] and their members through the lens of intermarriages, to fill a gap in the existing research, and to test the applicability of the vernacular religion framework on the field of Jewish studies, where it is so far only marginally represented' (p. I 8).

The research questions are:

How did Finnish legislative changes affect the policies of the Jewish Communities of Helsinki and Turku with regard to Jewish intermarriages over the course of the twentieth century?

What kind of challenges relating to intermarriage and conversion are brought to the fore in the ethnographic material, and what strategies have the informants created to handle them in their practice and in their views of Judaism/Jewishness?

Are there any differences between the vernacular practices of male and female informants of the study, and if so, how can these differences be described and understood? (p. I 8)

The topic - vernacular religion in the two (current) Finnish Jewish communities in Helsínki and Turku - is relevant from a scholarly perspective, and the research problem is concisely formulated. It is an excellent idea to use intermarriages as a prism to study vernacular religion and Jewish identity. This study indeed fills a gap, and it does so in at least two ways. Firstly, empirically through the archival and interview-based studies, and secondly through the perspective.

The analytical concepts are clearly defined and systematically and coherently used. The craftsmanship is exemplary. Czimbalmos makes excellent use of the tools chosen and has a pragmatic attitude to theories that is commendable. The central perspective, vernacular religion, is fruitful, and the elaboration of it as 'doing, being, and thinking Jewish' is both innovative and convincing, although the author does not present a method to assess it." The employment of the findings in previous (US) scholarship on conversions as empirical generalisations to establish categories/themes for the analysis of the Finnish case also works well. However, a few other aspects could have been included/elaborated. Since the project addresses identity, how members of the Finnish Jewish communities negotiate their Jewishness, the author might have considered using identity and identity-formation theories. The author discusses such theories and Jewish identity as a context and as previous research, but not as a theoretical underpinning. Another perspective that is employed, and successfully so, is gender. Considerations regarding gender even inform the research design. One study on men in mixed marriages and one on women and a comparison of the two reveal significant differences. One of the main results of the thesis is that doing, being and thinking Jewish are remarkably gendered practices. Therefore, it might have

* Vernacular religion is, following Leonard Norman Primiano, defined as: 'religion as it is lived: as human beings encounter, understand, interpret, and practice it' (p. 39). It is stressed (and also amply demonstrated in the thesis, not least in the analysis of how legislative changes affected the community from I 9 I 8 and onwards) that 'the vernacular approach enables multidimensional analyses that are sensitive to both overarching sociocultural power structures and the inner world of individual subjects themselves, as well as to narrative structures, local practices, and oral histories' (p. 39) and that it is therefore suited for the kind of study here discussed and I agree. 
been a good idea to discuss gender in the theory section.

Furthermore, the discussion of the categories and subcategories of marriages could have been elaborated. The types used work very well in the analysis, but they are not self-evident. For instance, 'religious' marriage could have been mentioned as a separate category. In addition, three other types of 'marriages' might have been discussed: couples who choose to live together without being married, for example cohabitation; marriages where both spouses are halakhically Jewish; and same-sex marriages (both endogamous and exogamous). Cohabitation is mentioned, but the author claims that it would have required too much additional work to include couples living together without being married, and maybe that is also the case. However, it would have been interesting to compare how Jewish is being done, etc. by people in the different types of marriage analysed here with couples who have chosen not to marry and with couples where both spouses are Jews according to halakhic definition (and of different or the same sex). Cohabitation is relevant to study because it helps circumvent some of the complications common in mixed and same-sex relations. The endogamous category is interesting since spouses in such a marriage in some ways have leeway. However, I am not suggesting that further studies should have been conducted, only that these other types of 'marriages' could have been discussed when assessing the outcome of the cases studies.

The author uses a variety of methods. They are all clearly explained and motivated and skilfully and consistently used. However, since comparisons are a characteristic of the thesis, comparative aspects could have been stressed. The author makes both a diachronic (the first article) and a synchronic comparison (the comparison between the results in the three interview-based studies), and uses the findings from the longitudinal archivebased investigation in the interview studies but does not systematically discuss these comparisons as a part of her method. This is a pity, especially regarding the diachronic aspects. Had the author explicitly discussed comparisons as a method and formulated a research question concerning continuity and change, she could have highlighted her results concerning what changed and why and what remained unaffected in the Finnish Jewish marriage patterns and the strategies employed.

One way to facilitate an analysis stressing continuity and change could have been to systematically use the results of an extensive survey carried out by the author. Alas, the survey results are only used to formulate questions for the interviews. The argument for not including it as a separate study - the low response rate (around ro per cent) - is reasonable and legitimate. However, leaving the survey out means that an opportunity is missed for both a systematic diachronic and a more systematic Nordic/Scandinavian comparison - the latter, furthermore, being one of the objectives of Minhag Finland. Omitting the survey rules out a systematic comparison with a similar study by Svante Lundgren (conducted in 2000 and published in 2002) and thus a diachronic comparison. This, in turn, has consequences for the comparisons with Lars Dencik's and David Fisher's studies of Swedish marriage patterns and thus for a discussion of a possible Nordic-Jewish marriage pattern. The author presents the main results in Lundgren's, Dencik's and Fisher's works, but they are not, in the same way as the American studies on conversions and intermarriage, a part of the analytical framework.

A few words about the thematic analyses (TA) employed are necessary to conclude the discussion of methodology. The themes used 
result from both a bottom-up and a topdown approach, and the author uses them skilfully in the analysis. The main themes are 'emotional connections to Jewish tradsitions, approaches of observing Jewish traditions, experiences of inclusion and exclusion and experiences of being and doing Jewish in Finland' (p. 52). They are organised in different ways in the different articles. In the studies of Jewish women and men in mixed marriages, the themes are divided into four main domains: 'Jewish holidays and traditions, kashrut; Jewish education of (future) offspring and brit milab' (ibid.). In the study of conversions, the categorisation is based upon Sylvia Barack Fishman's model, where the informants are divided into three categories: 'activist, accommodating, and ambivalent converts'. As a result of the analysis, the author modified this categorisation slightly and added the category of 'cultural converts'. The presentation of the Thematic Analysis and the themes created (pp. 52, $65-7)$ is reasonable. However, it could have been slightly more specific, and it would have been helpful if the coding schedule had been added to the appendix.

The presentation of the sources and the collection and selection of data is clear and concise. Four types of materials are used. The most important category is the interviews with members (over the age of I 8 ) of the Jewish communities in Helsinki and Turku, Ior in total in the Minhag Finland project as a whole, of which 28 (for articles II and III) plus ro (for article IV) are used in the thesis. Furthermore, the author interviewed people who, in the r970s and r980s, had a central role in the Helsinki community and used their archives. In addition, she has, as mentioned above, conducted a survey based upon similar surveys conducted in other European countries, and not least Lundgren's survey published in 2002 . Finally, the author has utilised (and also organised and digitised) vast amounts of archival sources from the communities studied (records, minutes from board meetings, correspondence etc.) and also from the Jewish community in Stockholm (article I).

The interviews were collected in 2018-19. They are semi-structured (and lasted I $1 / 2-2$ hours each). The informants were asked about 'family origin, upbringing, dietary habits, family and personal life, local customs in the synagogue and the home, as well as perceptions of Judaism and the self' (p. 47). The author identifies her position as an interviewer as a 'participant-as-observer'. Czimbalmos has done impressive work in the archives, sifting through vast quantities of documents of different kinds. Furthermore, the archival research results inform the interview-based studies; they provide themes for the analysis of the interviews. However, Czimbalmos could have been more specific, especially when describing and discussing the archival sources from the Helsinki, Turku and Stockholm communities. Which type of sources were used to answer which questions? How did the minutes from the board meetings complement the marriage and birth registries? What was found in the correspondence, and what was found in the archive of Rabbi Uri Schwarz? How was Meliza Amity's genealogical database utilised?

What then are the main results? The longitudinal study based on archival sources convincingly demonstrates that the Finnish bureaucratic and legislative regulations, especially the I9I 7 Civil Marriage Act and the 1922 Freedom of Religion Act, 'affected the policies, customs, and habits of the Jewish Community of Helsinki' (p. 36). The rising number of intermarriages, (in part) a consequence of these regulations, caused changes in the community's 'religious practices and administrative system' resulting in 'policies 
that affected not only the registration of membership but also the later policies of the congregation' (ibid.), not least regarding conversions. This affected the debates on and the understanding of Jewish identity.

The interview studies show that Jewish women in mixed marriages 'often combine models from different traditions instead of abandoning Judaism altogether; they "do Judaism" in their own way by creating and [re-]inventing traditions they find meaningful for themselves and their families' (p. 36). On the other hand, Jewish men in mixed marriages 'used their ties to their cultural heritage to increase their ability to raise their children effectively' (ibid.). Furthermore, the 'practices of intermarried Jewish men and their families are ... polarized by certain attributes of the gender-traditional realm of Judaism' (ibid.). It is thus evident that 'the gender differences among the informants are remarkable' (p. 85). Doing, being and thinking Jewish are heavily gendered practices.

The thesis also offers new knowledge regarding conversions. The converts all went through the formal conversion process to Judaism after becoming romantically involved with their Jewish partners. However, they 'did not convert for only personal reasons but also to secure the unity of their families and to be able to provide a Jewish upbringing to their children through a form of cultural transmission that was developed in the Finnish Jewish communities during the twentieth century' (p. 37). Czimbalmos notes that 'this form of transmission might not necessarily follow an Orthodox perception of tradition, despite the local congregations following a form of the Orthodox Jewish halakha, but it is enhanced by the fluid approaches of both the congregations and their members' (ibid.). The conversions are also gendered in nature 'despite the practice of early childhood conversions of children from intermarriages' (p. 85).
Czimbalmos concludes that in the Finnish Jewish context, 'Judaism is a truly "practicebased religion”. The practices through which the informants ... establish their Jewish identities, however, are often closely tied to Jewish culture rather than to Jewish religion' (p. 86).

These results are convincing and presented in constant dialogue with previous research, making it easy to identify Czimbalmos's original and most important contributions to the field. She set out to fill a gap, and she did.

LARS M. ANDERSSON

Faculty opponent, senior lecturer at the Department of History and Director of the Forum for Jewish Studies at the Department of Theology, both at Uppsala University 